\title{
Effect of Laser Cleaning on Granite Color
}

\section{Carlota M. Grossi, ${ }^{1 *}$ Francisco Javier Alonso, ${ }^{2}$ Rosa M. Esbert, ${ }^{2}$ Araceli Rojo ${ }^{2}$}

\author{
${ }^{1}$ School of Environmental Sciences, University of East Anglia, Norwich NR4 7TJ, United Kingdom \\ ${ }^{2}$ Department of Geology, University of Oviedo, Oviedo 33005, Spain
}

Received 21 September 2005; revised 22 February 2006; accepted 10 August 2006

\begin{abstract}
This article presents the effect of laser radiation on the color of ornamental granites used for external cladding. The laboratory experimentation was undertaken on a widely used coarse-grain granite commercially known as Rosa Porriño. The irradiation was carried out with a $Q$-switched Nd:YAG laser at $1064 \mathrm{~nm}$ and several energy densities (fluences) on polished surfaces, dry and wet, uncoated, and artificially coated-simulating a black crust. Laser effects on the granite surface were determined by color measurements with a colorimeter. These measurements made possible to determine probable damage due to laser radiation and the diverse response of different minerals. The analysis of the data also suggests potential causes for the color change and applicability limits of the technique. The $a^{*}$-parameter, or red-green component, is the most affected, leading to a change in $h_{a b}$ (hue) and was interpreted as a result in variations in the Fe compounds, which strongly condition stone color. No significant changes in $L^{*}$ (luminosity or lightness) or $C_{a b}^{*}$ (chroma) may indicate no relevant alterations in the surface polish. When using laser irradiation to remove black layers on granite surfaces, variations of $L^{*}$ can be indicative of the cleaning effectiveness. This research results may be useful to select laser parameters when managing ornamental granite cleaning operations. However, they also suggest the need of further experimentation in specific techniques of analysis as well as different laser wavelengths. (C) 2007 Wiley Periodicals, Inc. Col Res Appl, 32, 152159, 2007; Published online in Wiley InterScience (www.interscience. wiley.com). DOI 10.1002/col.20299
\end{abstract}

Key words: colorimetry; stone conservation; Nd:YAG laser cleaning; ornamental granite; Rosa Porriño

*Correspondence to: Carlota M. Grossi (e-mail: c.grossi-sampedro@ uea.ac.uk).

Contract grant sponsor: CICYT-Spain; Contract grant numbers: 1FD97-0331-C03-01, MAT2004-06804-C02-01.

(C) 2007 Wiley Periodicals, Inc.

\section{INTRODUCTION}

The application of laser radiation to the cleaning of stone was first investigated at the beginning of the seventies by Asmus, Hempel, Lazzarini, Marchesini, Beloyannis, and others. ${ }^{1}$ Laser cleaning of decayed stone and other materials in sculptures was also tested in museums and laboratories. These experiments were aimed at the removal of black crusts and soiling layers; i.e., Asmus ${ }^{2}$ conducted experiments on the cleaning of several Carrara marble sculptures in Florence and Venice.

Laboratory and on-site testing was carried on throughout the following decade. However, laser radiation was not applied to the cleaning of building stones until 1992, when a Nd:YAG laser device was used to clean the façade of the Virgin of the Amiens Cathedral. ${ }^{3-5}$ Since the beginning of the nineties laser cleaning of stone has become a relatively common conservation/restoration practice in both laboratory and monument contexts.

In Spain laser technology has been applied in the cleaning of polychrome on wood, ${ }^{6}$ chromatic patinas on monumental stones, ${ }^{7}$ ornamental gypsum, ${ }^{8,9}$ and patinas and black crust on building stone. ${ }^{10}$

The stone materials cleaned by laser radiation are mainly carbonate rocks_-limestones and marbles_-and, to a lesser extent, silicate rocks such as sandstones. Experience with granite and other crystalline stones (e.g., igneous rocks) is rare at present. ${ }^{11}$ This is one reason for this study to focus on the effects of laser cleaning on granite materials, which are widely used in the Spanish architectural heritage, especially in western (Galicia and Extremadura) and central areas (Madrid and Castilla-León).

The pulsed mode solid-state Nd-YAG laser at the fundamental wavelength of $1064 \mathrm{~nm}$ is the most widely type of laser used for cleaning building stone. The term YAG is an abbreviation for Yttrium Aluminum Garnet, which is the crystalline matrix hosting the $\mathrm{Nd}$ ions. This type of laser is generally considered the most suitable for the cleaning of some types of stones, such as limestones, because of its ability for the selective removal of dirt. 
TABLE I. "Rosa Porriño" granite characteristics.

Origin

Porriño, Pontevedra (Spain)

Texture
Average grain size (mm)
Open porosity (\%)
Dominant color
$\mathrm{Fe}_{2} \mathrm{O}_{3}{ }^{\mathrm{a}}$ content (\%)

a Determined by $\mathrm{X}$-ray fluorescence.

Black damage layers absorb much more laser radiation at this wavelength than the calcitic material and consequently, they can be eliminated with minimal damage to the substrate. Meanwhile, short pulse lengths prevent thermal conductivity on the stone surface. ${ }^{1}$

The effects of laser cleaning on stones largely depend on the laser parameters (wavelength, pulse energy, pulse duration, and pulse frequency rate), the type of stone and the characteristics of application. ${ }^{12}$ Laser cleaning is only safe within a given range of parameter values. Irradiation on wet surfaces usually decreases the probability of thermal and mechanical damage and also increases the efficiency of cleaning. ${ }^{1,13,14}$

The chemical and mineralogical composition of the materials affects the absorption to laser radiation and therefore possible chemical and physical changes and their concomitant color-related behavior. Color is one of the stone characteristics that influence its use as a building material. Changes in stone color can be publicly acceptable but also aesthetically unpleasant. Therefore color is a property that is often measured when undertaking research in conservation, ${ }^{15,16}$ specially when using laser cleaning. ${ }^{17,18,19,20}$ Rock color is strongly influenced by the content, oxidation state and types of iron compounds, as iron is highly absorbent to laser radiation at $1064 \mathrm{~nm}$. In general, color changes are usually attributed to changes in the state of oxidation of iron compounds ${ }^{13,14,19}$. Cooper ${ }^{1}$ recommends caution when applying this type of laser to materials, such as sandstone and granite, because of the presence of mica and iron oxide, both highly absorbent to the $1064 \mathrm{~nm}$ radiation. Wavelengths other than the fundamental $1064 \mathrm{~nm}$ need to be tested for the cleaning of some specific stones. Nowadays, there is an increasing research on the use of the Q-switched Nd-YAG different harmonics (1064, 532, 355, and $266 \mathrm{~nm}$ ) for different cleaning purposes of historic stone. ${ }^{21}$

This work studies the effects of Q-switched Nd-YAG laser at $1064 \mathrm{~nm}$ used to clean ornamental granites. The research is challenging and relevant for stone conservation practice as the polymineralic nature of granite complicates the color response to this type of cleaning procedure. The main objective is to establish the limits of applicability of this technique for the cleaning of a pinkish-colored granite, as well as the causes of granite response to laser radiation. That was approached through color change measurements and examination of the cleaned surfaces using scanning electronic microscopy (SEM).

\section{EXPERIMENTAL}

\section{Material}

Experiments were carried out on a granite commercially identified as Rosa Porriño, one of the most widely known and internationally used Spanish ornamental stones. Rosa Porriño is a biotite granite of phaneritic, coarse grained (5-30 mm), hypidiomorphic, and heterogranular texture. The essential minerals are quartz, microcline, plagioclase (An 8-28), and biotite; the accessory minerals are apatite, allanite, zircon, sphene, and opaque minerals (including molybdenite and rutile) and the secondary minerals are chlorite (biotite alteration), epidote, and sericite (plagioclase alteration). The largest crystals are microcline. As a result of this mineralogy and crystal size, the rock is polychromatic, pink being the dominant tone. Its petrographic characteristics, ${ }^{22}$ modal analysis, crystal size, and mineral colors are summarized in Tables I and II.

\section{Experimental Methodology}

\section{Color Changes}

The experiment was undertaken on stone tablets of 50 $\mathrm{mm} \times 50 \mathrm{~mm} \times 10 \mathrm{~mm}$ (exposure surface of $2500 \mathrm{~mm}^{2}$ ) on polished uncoated and artificially coated surfaces, both dry and moistened with water spray. Three granite slabs were used in each case.

We used the uncoated surfaces-reference blanks- to study the effects of laser radiation on the granite. The artificially coated surfaces were used to study the effectiveness of laser cleaning to remove black layers from granite surfaces.

The $\sim 0.5-\mathrm{mm}$ thick coating consisted of $35 \mathrm{~g}$ of gypsum, $50 \mathrm{~g}$ of lime, $75 \mathrm{~g}$ of marble powder as inert loading, $15 \mathrm{~g}$ of black smoke pigment, $15 \mathrm{~g}$ of black vine pigment and deionized water. The proportion of the mixture in weight was two parts deionized water for every 2.5 parts of the above preparation.

TABLE II. Modal analysis, size, and color of the constituent minerals of "Rosa Porriño" granite.

\begin{tabular}{lcccc}
\hline & Quartz & Potassium feldspar & Plagioclase & Biotite \\
\hline Structural formula & $\mathrm{SiO}_{2}$ & $(\mathrm{~K}, \mathrm{Na})\left[\mathrm{AlSi}_{3} \mathrm{O}_{8}\right]$ & $\mathrm{Na}\left[\mathrm{AlSi}_{3} \mathrm{O}_{8}\right] \mathrm{Ca}\left[\mathrm{AlSi}_{2} \mathrm{O}_{8}\right]$ & $\mathrm{K}\left(\mathrm{Mg}_{,}, \mathrm{Fe}{ }^{2+}\right)_{3}\left[\mathrm{AlSi}_{3} \mathrm{O}_{10}(\mathrm{OH}, \mathrm{F})_{2}\right]$ \\
Modal analysis $(\%)$ & $30 \pm 2$ & $48 \pm 3 \pm 1$ & $9 \pm 4$ \\
Size $(\mathrm{mm})$ & $10 \pm 7$ & $17 \pm 6$ & $7 \pm 3$ & $3 \pm 1$ \\
Color & Dark grey & Light pink & White & Black \\
\hline
\end{tabular}




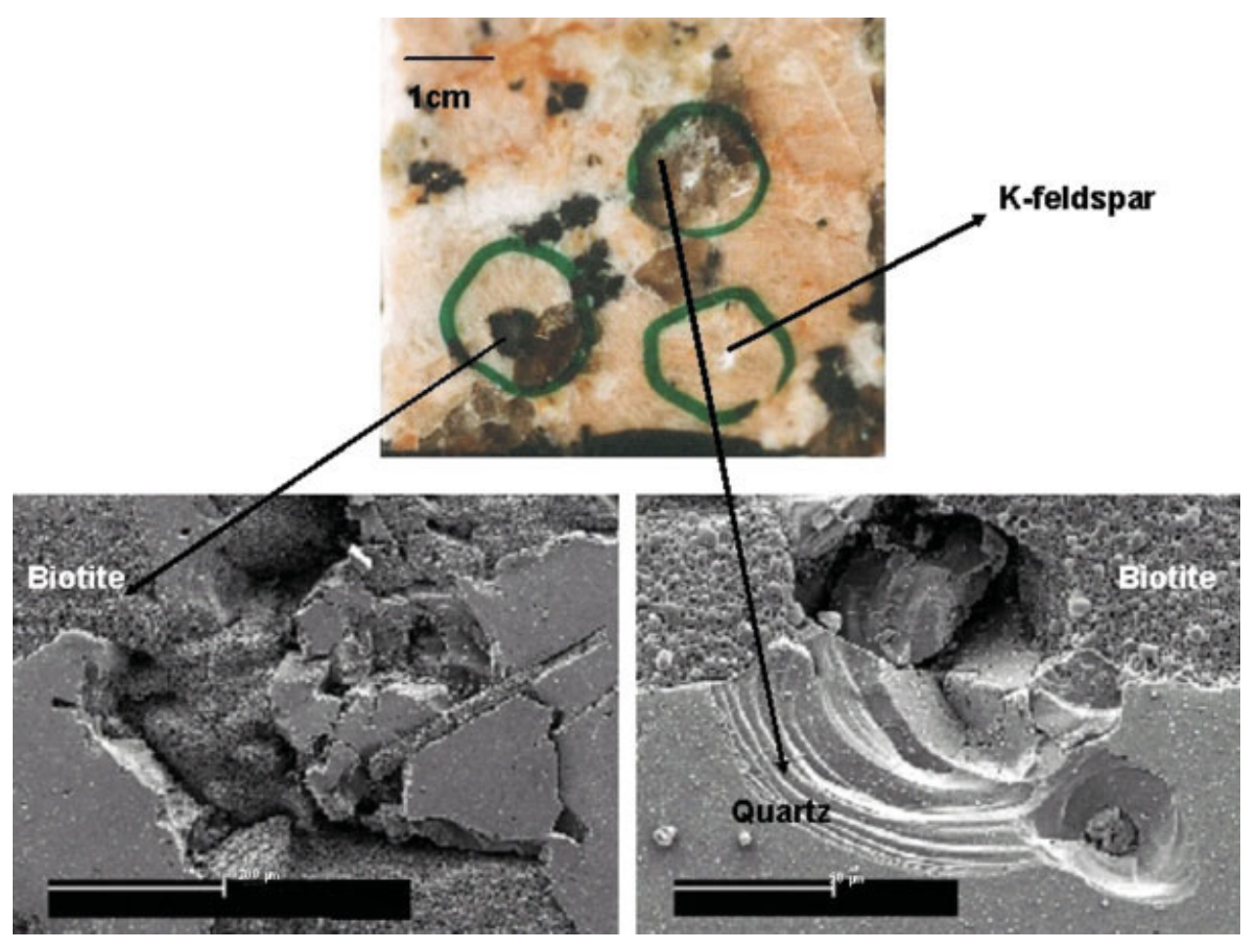

FIG. 1. Rosa Porriño granite irradiated with Nd:YAG $1064 \mathrm{~nm}$ at $1.25 \mathrm{~J} \mathrm{~cm}^{-2}$ and 10 pulses. SEM photographs (from Esbert et al. $^{20}$ ) show biotite melting and cleavage stepped fracture in quartz.
The samples were irradiated using a Q-switched $\mathrm{Nd}$ :YAG laser at $\lambda=1064 \mathrm{~nm}$, theoretical spot diameter $=6 \mathrm{~mm}$, pulse frequency rate $=20 \mathrm{~Hz}$; pulse duration $=$ $6 \mathrm{~ns}$ and two different fluences or energy densities: 0.5 and $1.47 \mathrm{~J} \mathrm{~cm}^{-2}$. The fluence $0.5 \mathrm{~J} \mathrm{~cm}^{-2}$ is slightly higher than that applied to conservation works when using this particular equipment. Esbert et $a{ }^{20}{ }^{20}$ reported color changes in this granite from a fluence of $0.5 \mathrm{~J} \mathrm{~cm}^{-2}$ onwards. The energy density $1.47 \mathrm{~J} \mathrm{~cm}^{-2}$ is the maximum fluence of the used equipment.

Color was measured prior to and after laser irradiation with the MINOLTA CR-200 colorimeter using the illuminant $\mathrm{C}$, beam of diffuse light of 8 -mm diameter, $0^{\circ}$ viewing angle geometry, specular component included and spectral response closely matching the CIE (1931) standard observer curves. Sixty shots were used in each test.

Color measurements are expressed using the CIE$L^{*} a^{*} b^{*}$ and CIE- $L^{*} C_{\mathrm{ab}} h_{\mathrm{ab}}$ systems. Here $L^{*}$ is the variable lightness or luminosity, which varies from 0 (black) to 100 (white); $a^{*}$ and $b^{*}$ are the chromatic coordinates; $+a^{*}$ is red, $-a^{*}$ is green, $+b^{*}$ is yellow, and $-b^{*}$ is blue. The attributes of chroma ( $C_{\mathrm{ab}}^{*}$ : saturation or color purity) and hue $\left(h_{\mathrm{ab}}\right.$ : referring to the color wheel) can be calculated by the equations: $C_{\mathrm{ab}}^{*}=\left(a^{*^{2}}+b^{*^{2}}\right)^{1 / 2}$ and $h_{\mathrm{ab}}=$ $\tan ^{-1}\left(b^{*} / a^{*}\right)$. Color differences $\left(\Delta L^{*}, \Delta a^{*}, \Delta b^{*}, \Delta C_{\mathrm{ab}}^{*}\right.$, $\left.\Delta H_{\mathrm{ab}}^{*}\right)$ were calculated after cleaning ${ }^{23}$ and the total color change $\left(\Delta E_{\mathrm{ab}}^{*}\right)$ was estimated by the expression: $\Delta E_{\mathrm{ab}}^{*}=$ $\left(\Delta L^{* 2}+\Delta a^{*^{2}}+\Delta b^{*^{2}}\right)^{1 / 2}$. Values of $\Delta E_{\mathrm{ab}}^{*}$ were assigned a gray scale (GSc) rating following recommendations of the European Standard: EN ISO 105-A05: $1997 .{ }^{24}$ In this standard GSc values indicate human visual discrimination to color differences; they vary from 5 (nonvisible changes) to 1 (very strong changes) and relate to intervals of $\Delta E$ from $<0.40$ to $\geq 11.60$. The significance of color changes was analyzed using the Mann-Whitney nonparametric test.

\section{Morphological Examination}

A series of smaller samples $(20 \mathrm{~mm} \times 20 \mathrm{~mm} \times 8 \mathrm{~mm})$ exhibiting polished, dry, and uncoated surfaces were analyzed for possible morphological changes because of the laser radiation. The specimens were irradiated at different fluences and pulse number, and then examined under the scanning electronic microscope (SEM). Here we tried to maximize the aggressiveness of the test by focusing the laser beam onto a precise area and using a variable number of pulses: 1, 10, and 100. The areas were selected in such a way that different granite minerals, i.e., quartz, potassium feldspar, and biotite, could be independently examined for any potential morphological damage (Fig. 1).

\section{RESULTS AND DISCUSSION}

The color of the granite is a combination of the color of its constituent minerals, which can vary slightly depending on the selected block. Table III shows the average values of the initial color parameters of the granite, its predominant minerals and the coated surfaces.

Rosa Porriño exhibits a predominantly pink hue as a result of its main and bigger minerals, which are pinkish and light colored (Tables II and III). Plagioclase (white) shows high luminosity values $\left(L^{*}\right)$ and low $a^{*}$ values. Potassium feldspar (pink) shows higher values of $a^{*}$ and $b^{*}$. The darker areas (mainly consisted of quartz and biotite) 
TABLE III. Initial values of color parameters of the constituent minerals (uncoated granite) and the coated surface.

\begin{tabular}{lcrrrr}
\hline & $L^{*}$ & $a^{*}$ & $b^{*}$ & $C_{\mathrm{ab}}^{*}$ & $h_{\mathrm{ab}}$ \\
\hline $\begin{array}{l}\text { Uncoated granite } \\
\quad \text { K-Feldspar (pink and }\end{array}$ & 62.5 & 3.3 & 7.8 & 8.6 & 69.0 \\
$\quad$ some white) & 69.5 & 5.9 & 11.5 & 13.0 & 64.9 \\
$\quad \begin{array}{l}\text { Plagioclase (white) } \\
\quad \text { Quartz and biotite (grey) }\end{array}$ & 73.6 & -0.1 & 6.8 & 6.9 & 90.8 \\
Coated granite & 33.2 & 1.4 & 4.3 & 4.5 & 73.2 \\
\hline
\end{tabular}

${ }^{a}$ The size of pinkish minerals (microcline: K-feldspar) allowed relatively easy colour measurement of individual crystals. The small size of the blackish biotite made color measurements of individual grains difficult. Biotite frequently appeared closed to quartz crystals. Quartz (although transparent) showed a grayish tone. Therefore, it was decided to give an averaged valued of these two minerals.

show low $L^{*}$ values. The black coating exhibits $L^{*}$ values that are very close to 30 (typical of blackened materials) and $a^{*}$ and $b^{*}$ values that are very close to 0 (very low chroma, close to grey).

The effects of laser on the color are mainly related to the pinkish minerals and are detailed in Table IV and Fig. 2. Table IV shows initial color parameter values (prior to the application of the coating), and final (after laser application), as well as their differences. In the case of coated surfaces, initial color refers to the original clean surface and final color to coated and subsequent laser cleaned surfaces. The resulting global color changes $\left(\Delta E_{\mathrm{ab}}^{*}\right)$ and their approximate corresponding values in the gray scale rating (GSc) are summarized in Table V. Finally, Table VI shows the percentage of initial color recovery in coated specimens once they have been cleaned with laser radiation (cleaning efficiency). This percentage was calculated as the ratio between the color of coated and subsequent laser cleaned surfaces and the original color of clean surfaces.

In general, when laser radiation is applied, the uncoated Rosa Porriño granite experiences a visible color change associated to pink potassium feldspars, which become paler. The $a^{*}$ parameter shows a strong statistically significant decrease even at a $0.5 \mathrm{~J} \mathrm{~cm}^{-2}$ fluence (Table IV). Other experiments ${ }^{20}$ indicate that these variations may not be produced at lower fluences, such as $0.37 \mathrm{~J} \mathrm{~cm}^{-2}$. The $a^{*}$ decrease translates into an increase of $h_{\mathrm{ab}}$, showing a change towards more yellowish tonalities (Fig. 2). The global color change $\left(\Delta E_{\mathrm{ab}}^{*}\right)$ is always more noticeable at a higher fluence and it is always greater on dry surfaces (Table V). Changes in $b^{*}$ and $L^{*}$ are not statistically significant at $P \leq 0.05$ therefore there is not enough evidence to say that the measured final values are different from the original ones. Any changes could possibly be within the range of sample variability.

Prior to this experiment some color measurements were carried out on pink feldspars and in dark minerals (biotite and quartz) pre- and post-laser irradiation at a 0.63 $\mathrm{J} \mathrm{cm}^{-2}$ fluence to dry surfaces. The only apparent change was a decrease in the $a^{*}$ coordinate in pink minerals at a

TABLE IV. Average values of color parameters on uncoated and artificially coated specimens, before and after laser cleaning, for two different fluences $\left(0.5\right.$ and $\left.1.47 \mathrm{~J} \mathrm{~cm}^{-2}\right)$, and two modes of application (dry and moistened surface).

\begin{tabular}{|c|c|c|c|c|c|c|c|c|}
\hline & \multicolumn{4}{|c|}{ Uncoated surface } & \multicolumn{4}{|c|}{ Coated surface } \\
\hline & \multicolumn{2}{|c|}{$0.5\left(\mathrm{~J} \mathrm{~cm}^{-2}\right)$} & \multicolumn{2}{|c|}{$1.47\left(\mathrm{~J} \mathrm{~cm}^{-2}\right)$} & \multicolumn{2}{|c|}{$0.5\left(\mathrm{~J} \mathrm{~cm}^{-2}\right)$} & \multicolumn{2}{|c|}{$1.47\left(\mathrm{~J} \mathrm{~cm}^{-2}\right)$} \\
\hline & Dry & Moistened & Dry & Moistened & Dry & Moistened & Dry & Moistened \\
\hline$L^{*}$ initial & 61.8 & 62.5 & 61.5 & 63.1 & 64.7 & 62.5 & 61.1 & 62.8 \\
\hline$L^{*}$ coating & - & - & - & - & 33.2 & 33.2 & 33.2 & 33.2 \\
\hline$L^{*}$ final & 61.1 & 62.4 & 63.2 & 63.8 & 51.8 & 59.8 & 54.4 & 61.2 \\
\hline$\Delta L^{*}$ & $-0.6^{\text {ns }}$ & $-0.1^{\mathrm{ns}}$ & $1.7^{\mathrm{ns}}$ & $0.7^{\mathrm{ns}}$ & $-12.9^{a}$ & $-2.7^{\mathrm{b}}$ & $-6.8^{\mathrm{a}}$ & $-1.6^{\mathrm{ns}}$ \\
\hline$a^{*}$ initial & 3.7 & 4.0 & 2.9 & 3.5 & 3.4 & 3.2 & 2.7 & 3.3 \\
\hline$a^{*}$ coating & - & - & - & - & 0.3 & 0.3 & 0.3 & 0.3 \\
\hline$A^{\star}$ final & 2.2 & 2.9 & 1.1 & 1.6 & 2.6 & 2.7 & 1.8 & 2.1 \\
\hline$\Delta a^{*}$ & $-1.5^{\mathrm{a}}$ & $-1.1^{\mathrm{a}}$ & $-1.8^{\mathrm{a}}$ & $-1.9^{b}$ & $-0.8^{\text {ns }}$ & $-0.6^{\mathrm{ns}}$ & $-0.9^{\mathrm{b}}$ & $-1.2^{\mathrm{a}}$ \\
\hline$b^{\star}$ initial & 8.2 & 8.7 & 7.2 & 8.0 & 8.1 & 7.8 & 7.0 & 7.7 \\
\hline$b^{\star}$ coating & - & - & - & - & 0.3 & 0.3 & 0.3 & 0.3 \\
\hline$b^{\star}$ final & 7.6 & 8.6 & 7.2 & 7.8 & 8.2 & 8.7 & 7.6 & 8.6 \\
\hline$\Delta b^{*}$ & $-0.6^{\text {ns }}$ & $-0.1^{\mathrm{ns}}$ & $0.02^{\text {ns }}$ & $0.2^{\text {ns }}$ & $0.1^{\mathrm{ns}}$ & $0.8^{\text {ns }}$ & $0.6^{\text {ns }}$ & $0.8^{\text {ns }}$ \\
\hline$C_{\mathrm{ab}}^{\star}$ initial & 9.1 & 9.6 & 7.8 & 8.8 & 8.9 & 8.5 & 7.6 & 8.5 \\
\hline$C_{\mathrm{ab}}^{\star}$ coating & - & - & - & - & 0.4 & 0.4 & 0.4 & 0.4 \\
\hline$C_{\mathrm{ab}}^{\star}$ final & 7.9 & 9.1 & 7.3 & 8.0 & 8.6 & 9.1 & 7.8 & 8.8 \\
\hline$\Delta C_{\mathrm{ab}}^{\star}$ & $-1.2^{\mathrm{ns}}$ & $-0.5^{\mathrm{ns}}$ & $-0.6^{\text {ns }}$ & $-0.8^{\mathrm{ns}}$ & $-0.2^{\text {ns }}$ & $0.6^{\mathrm{ns}}$ & $0.2^{\mathrm{ns}}$ & $0.4^{\mathrm{ns}}$ \\
\hline$h_{\mathrm{ab}}$ initial & 67.5 & 66.7 & 71.3 & 66.9 & 69.8 & 68.6 & 71.6 & 69.6 \\
\hline$h_{\mathrm{ab}}$ coating & - & - & - & - & 43.6 & 43.6 & 43.6 & 43.6 \\
\hline$h_{\mathrm{ab}}$ final & 74.5 & 72.0 & 82.5 & & 72.8 & 73.8 & 77.5 & 76.7 \\
\hline$\Delta H_{\mathrm{ab}}^{*} \mathrm{c}^{\mathrm{c}}$ & $1.1^{\mathrm{a}}$ & $1.0^{\mathrm{a}}$ & $1.7^{\mathrm{a}}$ & $1.7^{\mathrm{a}}$ & $0.9^{b}$ & $0.7^{\mathrm{a}}$ & $1.2^{\mathrm{a}}$ & $1.4^{\mathrm{a}}$ \\
\hline
\end{tabular}

Coated surfaces: initial color refers to the original clean surface and final color to coated and subsequent laser cleaned surfaces. The number of color measurements both prior and post laser application was 60 in each case. ns, no significant changes.

a Significant changes at $P \leq 0.01$.

${ }^{b}$ Significant changes at $P \leq 0.05$.

${ }^{\mathrm{c}}$ Calculated following EN ISO $105-\mathrm{JO3}^{23}$ recommendations. 

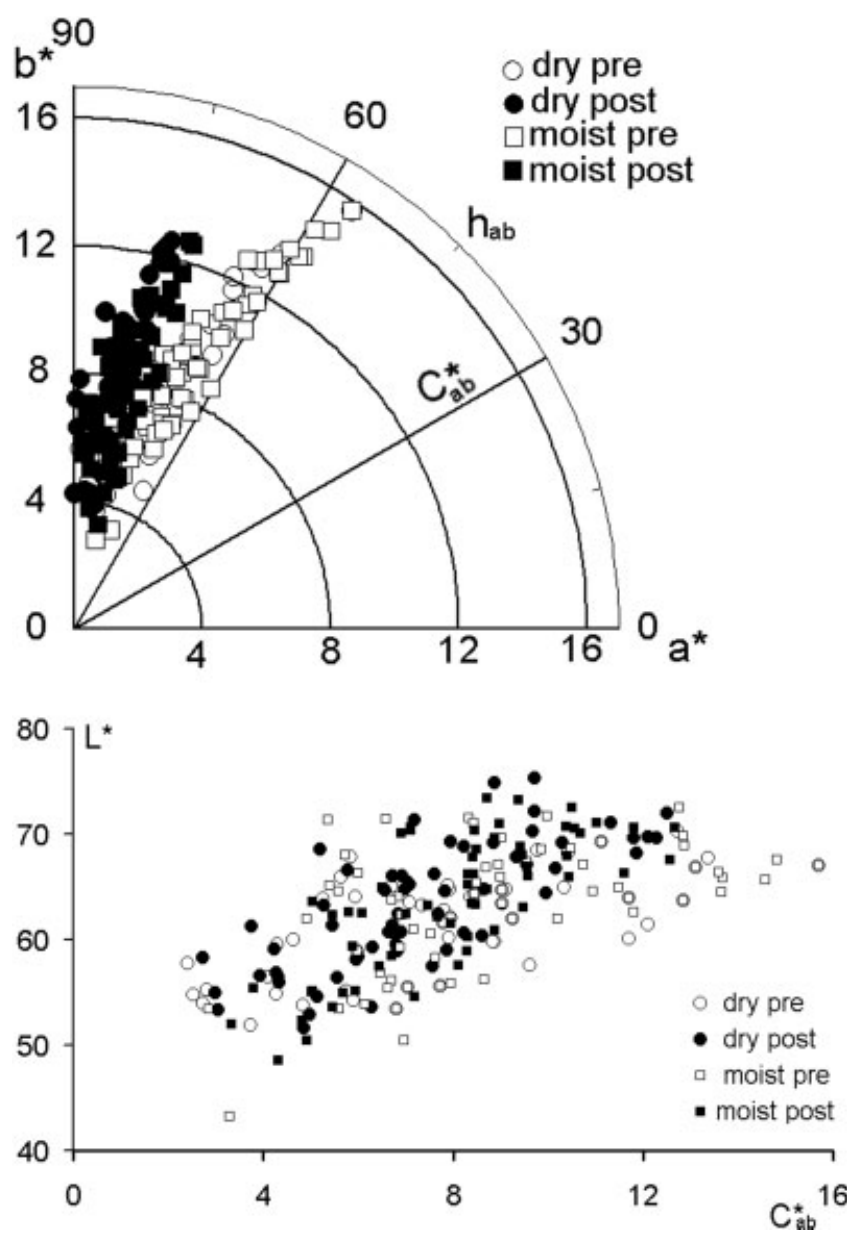

FIG. 2. Color parameters in Rosa Porriño prior and after laser irradiation at $1.47 \mathrm{~J} \mathrm{~cm}^{-2}$. Parameters $a^{*}$ and $h_{\mathrm{ab}}=$ $\tan ^{-1}\left(b^{\star} / a^{\star}\right)$ show the main significant changes.

ratio similar to those shown in Table IV (Fig. 3). However, the small number of measurements did not allow any statistical analysis.

In coated specimens, the color change after laser cleaning is mainly an effect of the rests of the coating layer on the material, and it is associated to a great extent to the $L^{*}$ parameter (luminosity or lightness). $L^{*}$ values are always lower than those prior to the application of the coating (Table IV), and therefore they are related to the amount of coating that is conserved, as opposed to the effects of laser radiation on the granite surface.

The elimination of the coating is always more effective on moistened surfaces, where the recovery of the global color and luminosity $\left(L^{*}\right)$ is above $90 \%$, both at 0.5 and at $1.47 \mathrm{~J} \mathrm{~cm}^{-2}$ fluences (Tables V and VI) -slightly higher at the highest fluence.

In coated specimens, there is also a change in color due to the laser effect associated with the $a^{*}$ coordinate. This effect on $a^{*}$ is stronger at the highest fluence. Table VI shows that even when the recovery of $L^{*}$ and $b^{*}$ is around $100 \%$ (in moistened surfaces), the recovery of $a^{*}$ is much smaller. The parameter $a^{*}$ is most probably affected by the laser radiation, leading to a decrease in positive $a^{*}$ values. The laser cleaning is not self-limiting in this case. For instance, at $1.47 \mathrm{~J} \mathrm{~cm}^{-2}$, the percentage of the $a^{*}$ value recovered is only $66 \%$, even though most of the coating is eliminated (around $89 \%$ in dry or $98 \%$ in moistened conditions). Moreover, this $66 \%$ is less than the $80 \%$ of the $a^{*}$ value recovered when the radiation fluence is $0.5 \mathrm{~J} \mathrm{~cm}^{-2}$.

In the case of moistened cleaning on coated specimens, there may be a slight increase in $b^{*}$, although it does not seem to be significant at $P \leq 0.05$. That increase was also observed in other materials under the same cleaning conditions. $^{20}$

Consequently, it seems that the main Rosa Porriño color changes are related to a significant decrease in the $a^{*}$ coordinate and could be associated to changes in the $\mathrm{Fe}_{2} \mathrm{O}_{3}$ contained in potassium feldspar. ${ }^{25}$ Vergara Pardeiro $^{26}$ found iron oxides concentrated as lamellas or stains in cleavage planes or fractures in Rosa Porriño feldspars and quartz associated to hematite and allanite. Color changes might be a result of thermal effects. Esbert et $a l^{20}$ and Grossi et al. ${ }^{27}$ observed in similar laser irradiation experiments that the $a^{*}$ coordinate in limestoneseven in whitish ones-was very sensitive to laser radiation. Reddish limestones, with higher positive $a^{*}$ values experienced larger color changes, mainly an $a^{*}$ decrease, leading also to changes in $h_{\mathrm{ab}}$ (hue). Visually, reddish stones turned into greener tones. They speculated that the detected changes could be associated to Fe-compounds. Coordinates $L^{*}$ and $b^{*}$ can also show changes, always a decrease, mainly in more chromatic stones, which translates into a general darkening and decrease in chroma. Other types of experiments with sandstone ${ }^{28}$ also showed that high temperatures can alter the $a^{*}$ parameter because of the changes in Fe-rich components.

In this experiment, Rosa Porriño does not show any statistical significant change in $L^{*}, b^{*}$ and $C_{\mathrm{ab}}^{*}$. Lightness $\left(L^{*}\right)$ and chroma $\left(C_{\mathrm{ab}}^{*}\right)$ changes have been found to be associated to changes in surface roughness. ${ }^{29}$ In our case, surface roughness measurements were not possible

TABLE V. Average global color changes $\left(\Delta E_{\mathrm{ab}}^{\star}\right)$ and Grey Scale values related to visible color change (GSc) for diverse tests and conditions, following EN ISO 105-A05 recommendations. ${ }^{24}$

\begin{tabular}{|c|c|c|c|c|c|c|c|c|}
\hline & \multicolumn{4}{|c|}{ Uncoated surface } & \multicolumn{4}{|c|}{ Coated surface } \\
\hline & \multicolumn{2}{|c|}{$0.5\left(\mathrm{~J} \mathrm{~cm}^{-2}\right)$} & \multicolumn{2}{|c|}{$1.47\left(\mathrm{~J} \mathrm{~cm}^{-2}\right)$} & \multicolumn{2}{|c|}{$0.5\left(\mathrm{~J} \mathrm{~cm}^{-2}\right)$} & \multicolumn{2}{|c|}{$1.47\left(\mathrm{~J} \mathrm{~cm}^{-2}\right)$} \\
\hline & Dry & Moistened & Dry & Moistened & Dry & Moistened & Dry & Moistened \\
\hline$\Delta E_{\mathrm{ab}}^{\star}$ & 1.7 & 1.1 & 2.5 & 2.0 & 12.9 & 2.9 & 6.9 & 2.2 \\
\hline GSc & 4 & 4.5 & 3.5 & 4 & 1 & 3.5 & 2 & 3.5 \\
\hline
\end{tabular}


TABLE VI. Average percentage of color recovery of coated specimens after laser irradiation.

\begin{tabular}{lrrrrr}
\hline & \multicolumn{2}{c}{$0.5\left(\mathrm{~J} \mathrm{~cm}^{-2}\right)$} & & \multicolumn{2}{c}{$1.47\left(\mathrm{~J} \mathrm{~cm}^{-2}\right)$} \\
\cline { 2 - 3 } \cline { 6 - 6 } & \multicolumn{1}{c}{ Dry } & Moistened & & Dry & Moistened \\
\hline$L^{*}$ & 80.1 & 95.7 & & 88.9 & 97.5 \\
$a^{*}$ & 76.3 & 82.3 & & 66.1 & 66.0 \\
$b^{*}$ & 101.2 & 110.6 & & 108.0 & 110.8 \\
Global & 60.5 & 90.6 & & 76.2 & 93.0 \\
\hline
\end{tabular}

Values of $100 \%$ imply no change in color.

Values $<100 \%$ imply changes by defect.

Values $>100 \%$ imply changes by excess.

Coated surfaces: initial color refers to the original clean surface and final color to coated and subsequent laser cleaned surfaces.

because no specific equipment was available in the laboratory at the time of the experimentation. Alternatively, color measurements were carried out on unpolished and polished granite surfaces. In agreement with Benavente et al., ${ }^{29}$ the different surface finishes exhibited different chroma and lightness but not significantly different hue. Polished surfaces showed higher chroma and lower lightness (Fig. 4). Hence, in this case, even if mechanical damage and roughening is quite plausible, the variation of surface roughness is not enough to overcome the variability of the $L^{*}$ and $b^{*}$ of this polychromatic material.

Therefore the significant changes associated to $a^{*}$ and $h_{\mathrm{ab}}$ when Nd:YAG 1064 is irradiated on Rosa Porriño polished surfaces suggest a chemical rather than a physical effect. Unfortunately, we could not assess changes in $\mathrm{Fe}$ states. However, X-ray Photoelectron Spectroscopy (XPS) seems a promising nondestructive technique to study Fe oxidation-reduction processes on granite surfaces. ${ }^{30}$

Finally, further and more aggressive experiments, focusing onto a specific point of a mineral and using a variable number of pulses were assessed by SEM. Biotite is the most affected mineral and can reach melting even at no very high fluences whereas Quartz shows thermally induced brittle fracture ${ }^{20}$ (Fig. 1). Feldspars show occasional pitting and spalling. This observed damage might also affect surface polish and eventually chroma and lightness. Visually, biotite exhibits a change to lighter tones and potassium feldspars become whitish at high fluences and pulse numbers (Fig. 1).

\section{CONCLUSIONS}

The exhaustive analysis of the variation of the color coordinates and SEM examination on Rosa Porriño demonstrate that irradiation with a Q-switched Nd:YAG laser at $1064 \mathrm{~nm}$ can be detrimental if high fluences are applied. The present research on granite polished surfaces is a relevant contribution to Stone Conservation practice as it made possible: (a) to determine possible damage due to laser radiation and the response of different minerals and (b) to suggest potential causes for the color change and applicability limits of the technique.
It seems that Fe compounds, very sensitive to $1064 \mathrm{~nm}$ laser radiation, strongly condition the response of granite to laser irradiation, especially regarding to color changes. The $a^{*}$ parameter, or red-green component, is strongly affected. Changes in $a^{*}$ could be related to thermal effects on the $\mathrm{Fe}_{2} \mathrm{O}_{3}$ likely contained in the feldspars. However, that was not assessed experimentally. The use of some surface nondestructive spectrometry, such as XPS, could be of interest for this type of studies.

Changes in different color parameters might indicate the nature of the damage. The $a^{*}$ decrease - and the consequent hue change-seems to indicate a predominant damage because of the chemical reactions of some granite com-
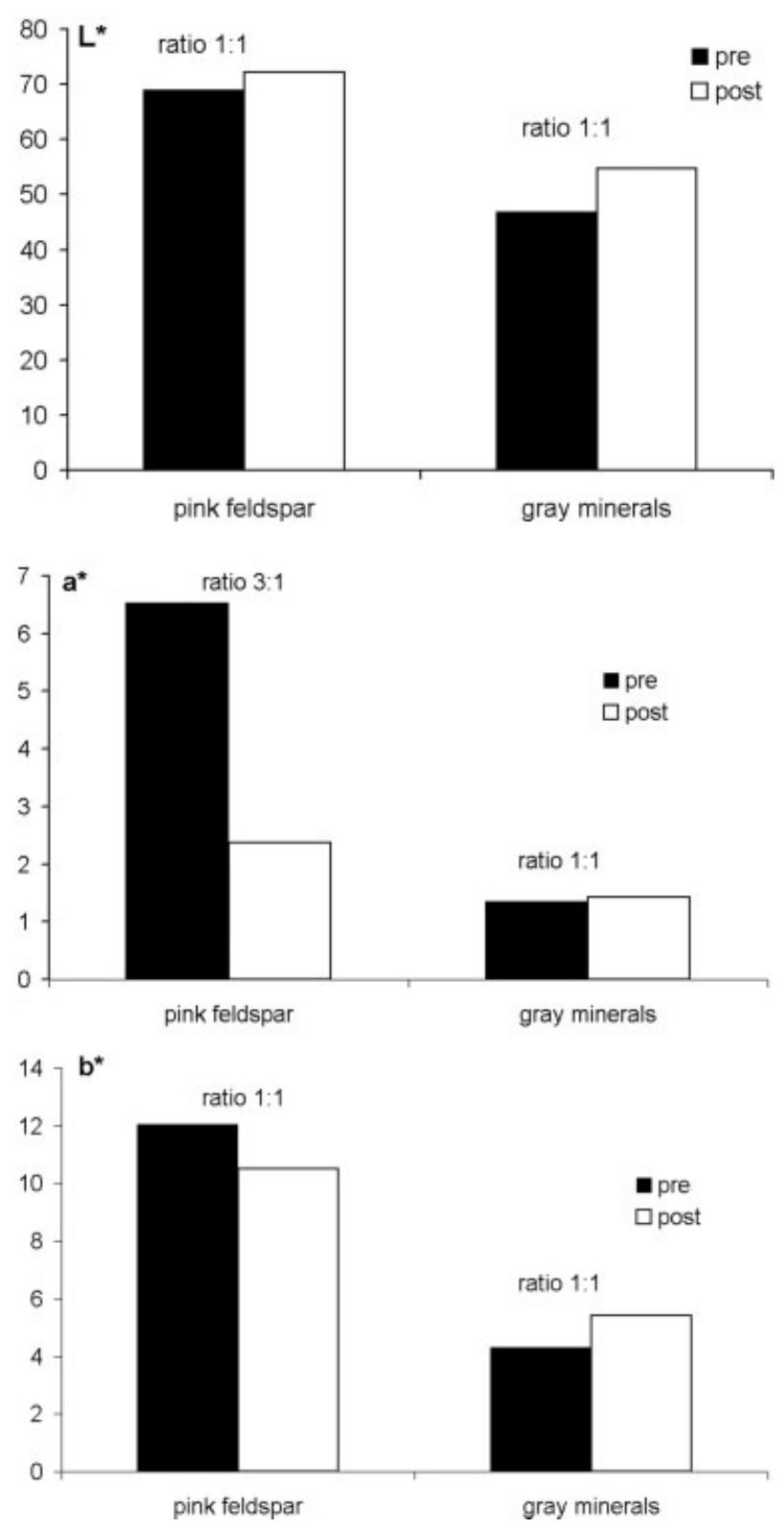

FIG. 3. Changes in the color parameters of dry surfaces of polished Rosa Porriño individual minerals or areas irradiated at $0.63 \mathrm{~J} \mathrm{~cm}^{-2}$. The parameter $a^{*}$ of pink feldspars shows the main change. 

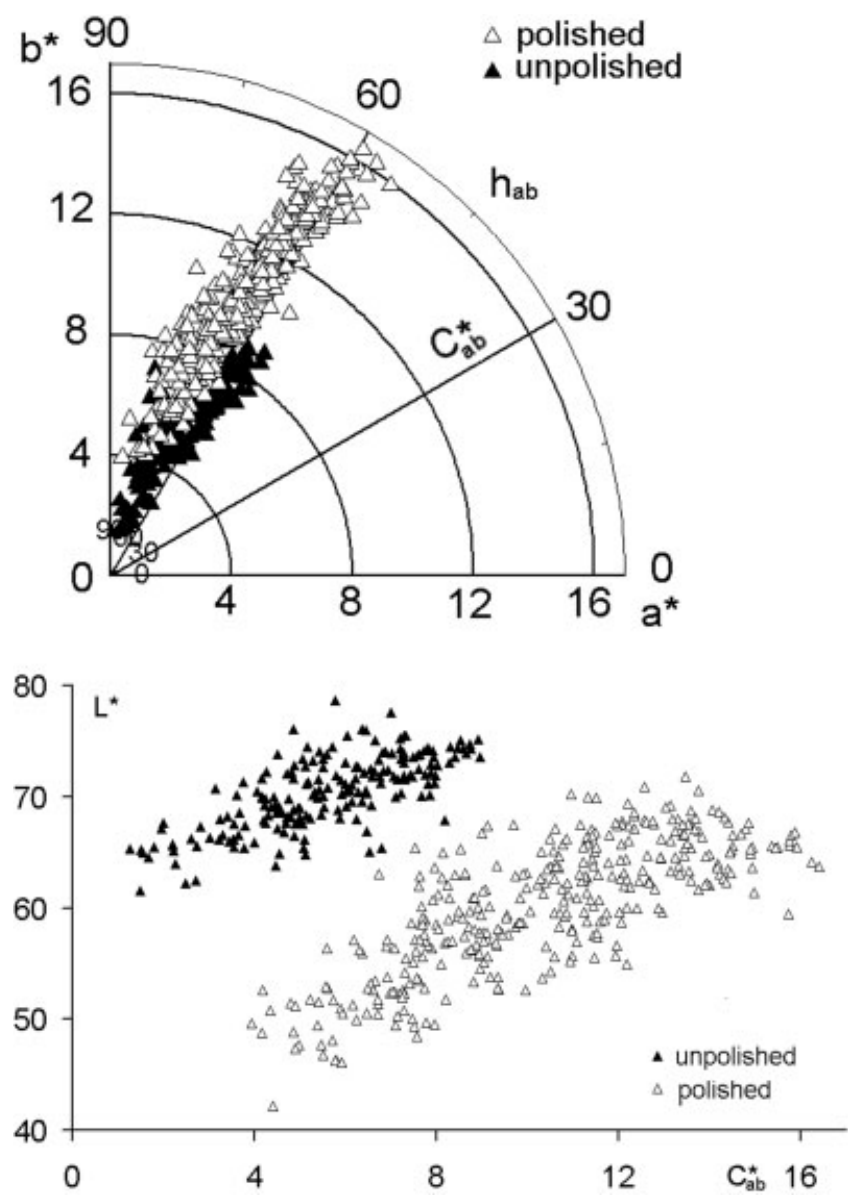

FIG. 4. Color parameters in Rosa Porriño polished and unpolished surfaces. Parameters $C_{\mathrm{ab}}^{\star}=\left(a^{\star 2}+b^{\star 2}\right)^{1 / 2}$ and $L^{*}$ show the main differences.

pounds when irradiated at a $1064 \mathrm{~nm}$ wavelength. In general, no significant $L^{*}$ or $C_{\mathrm{ab}}^{*}$ changes-sometimes related to variations in surface roughness-were detected. In the case of black coated surfaces the variations of $L^{*}$ because of the coating and posterior laser-removal of the black layers can be used as indicative of the cleaning effectiveness.

The above results might be of some utility in the management of ornamental granite conservation, mainly when selecting laser parameters and conditions of cleaning. The results also suggest the need of further experimentation on the use of different wavelengths and specific techniques of analysis.

\section{ACKNOWLEDGMENTS}

The authors acknowledge Prof. Peter Brimblecombe (University of East Anglia) and Ms. Cristina Escudero (Centro de Restauración-Junta de Castilla y León, Spain).

1. Cooper MI. Laser Cleaning in Conservation-An Introduction. Oxford, UK: Butterworth-Heinemann; 1998.

2. Asmus JF. The development of a laser statue cleaner. In: Proceedings of the second International Symposium on the Deterioration of Building Stones, Athens, 1976. pp 137-141.

3. Weeks C. The Conservation of the portal de la Mère Dieu, Amiens Cathedral, France. In: Kautek W, Köning E, editors. Lasers in the
Conservation of Artworks LACONA I. Vienna: Verlag Mayer \& Comp; 1997. pp. 25-29.

4. Orial G, Vergès-Belmin V. Monuments et technologie de pointe, le tour de France laser. Monumental 1995;10/11:22-35.

5. Groux D. El láser y sus características. Un ejemplo: Notre Dame la Grande de Poitiers. In: Rivera J, Altés J, González Fraile E, Sola JR, editors. Patrimonio, Restauración y Nuevas Tecnologías. Valladolid: Instituto Español de Arquitectura; 1999. pp 235-241.

6. Castillejo M, Martín M, Silva D, Strtoudaki T, Anglos D, Burgio L, Clark RJH. Laser-induced breakdown spectroscopy and Raman microscopy of pigment in polychromes. J Cult Heritage 2000;1:S297S302.

7. Escudero Remirez C, Barrera del Barrio M, Pérez de Andrés C. Studies and preservation techniques in monuments: The use of laser as a cleaning device. In: Galan E, Zezza F, editors. Protection and Conservation of the Cultural Heritage in Mediterranean Cities. Lisse: Balkema; 2002. pp 299-305.

8. García C, Prieto AC, Pérez B, Leal L. Comparative study of different cleaning methods on limestone samples, application of laser radiation in the cleaning of gypsum ornaments. In: Proceedings of Sixth International Conference on Non-destructive Testing and Microanalysis for the Diagnostics and Conservation of the Cultural and Environmental Heritage, Rome, Italy, 1999. pp 563-577.

9. García C, Prieto AC, Pérez B, Leal L. limpieza de soportes pétreos de valor artístico I. Actuación con tecnología láser sobre la fachada de la iglesia de "Las Francesas" de Valladolid. Boletín de la Sociedad Española de Mineralogía 1998;21A:92-93.

10. Valdeón L, Esbert RM. Seguimiento de los trabajos de conservación de la piedra. La Fachada de la Iglesia de San Isidoro de Oviedo. Loggia 2000;10:88-93.

11. Rojo A. Estudio de los cambios inducidos en la superficie de la piedra por limpieza con energía láser. Seminario de Investigación. Universidad de Oviedo, 2000. 91 p.

12. Rodríguez Narvarro C, Elert K, Sebastián E, Esbert RM, Grossi CM, Rojo A, Alonso FJ, Montoto M, Ordaz J. Laser cleaning of stone materials: An overview of current research. Rev Conserv 2003;4:6582.

13. Siano S, Fabiani F, Pini R, Salimbeni R, Giamello M, Sabatini G. Determination of damage threshold to prevent side effects in laser cleaning of Pliocene sandstone of Siena. J Cult Heritage 2000;1: S47-S53.

14. Labouré M, Bromblet P, Orial G, Wiedemann P, Simon-Boisson C. Assessment of laser cleaning on limestones and sandstones. J Cult Heritage 2000; 1:S21-S27.

15. García-Talegón J, Vicente MA, Vicente-Tavera S, Molina-Ballesteros E. Assessments of chromatic changes due to artificial ageing and/or conservation treatments of sandstones. Color Res Appl 2003; 23:46-51.

16. Fort RA, Mingarro F, López de Azcona MC, Rodríguez Blanco J. Chromatic parameters as performance indicators for stone clearing techniques. Color Res Appl 2000;25:442-446.

17. Lee JM, Steen WM. In-process surface monitoring for laser cleaning processes using a chromatic modulation technique. Intl J Adv Manufact Technol 2001;17:281-287.

18. Klein S, Fersanki F, Hildenhagen j, Dickmann K, Uphoff H, Marakis Y, Zafiropolous V. Discoloration of marble during laser cleaning by Nd:YAG laser wavelengths. App Surf Sci 2001;171:242-251.

19. Eichert D, Vergès-Belmin V, Kahn O. Electronic paramagnetic resonance as a tool for studying the blackening of Carrara marble due to irradation by Q-swithched YAG laser. J Cult Heritage 2000;1:S37S45.

20. Esbert RM, Grossi CM, Rojo A, Alonso FJ, Montoto M, Ordaz J, Pérez de Andrés C, Escudero C, Barrera M, Sebastián E, RodríguezNavarro C, Elert K. Application limits of Q-switched Nd:YAG laser irradiation for stone cleaning based on colour measurements. J Cult Heritage 2003;4:S50s-S55s.

21. Gómez-Heras M, Alvarez de Buergo M, Rebollar E, Oujja M, Castillejo M, Fort R. Laser renoval of water repellent treatments on limestone. Appl Surf Sci 2003;219:290-299. 
22. Rojo A, Alonso FJ, Esbert RM. Hydric properties of some Iberian ornamental granites with different superficial finishes: A petrophysical interpretation. Materiales de Construcción 2003;53,269:6172.

23. Textiles-Tests for colour fastness. Part J03: Calculation of colour differences. Geneva: ISO; 1997. EN ISO 105-J03.

24. Textiles-Tests for colour fastness. Part A05. Instrumental assessment of change of colour for determination of grey scale rating. Geneva: ISO; 1997. EN ISO 105-A05.

25. Deer WA, Howie RA, Zussman J. Rock-forming Mineral. London: Longmans; 1963. 696 p.

26. Vergara Pardeiro A. Contribución al estudio del color del granito "Rosa Porrino". Boletín Geológico y Minero 1993;104:65-71.
27. Grossi C, Brimblecombe P, Esbert RM, Alonso FJ. Color changes in architectural limestones from pollution and cleaning. Col Res Appl (in press).

28. Hajpál M, Török Á. Mineralogical and colour changes of quartz sandstones by heat. Environ Geol 2004;46:311-322.

29. Benavente D, Martinez-Verdú F, Bernabeu A, Viqueira V, Fort A, García del Cura MA, Illueca C, Ordoñez S. Influence of surface roughness on color changes in building stones. Col Res Appl 2003; 28:343-351.

30. García del Cura MA, Bernabéu MA, Benavente D, Cañaveras JC, Ordoñez. A pathology in plutonic ornamental rocks: the discolouration of ornamental black granite (gabro). The Zimbabwe Black case. In: III Congreso Ibérico de Geoquímica, Zaragoza; 2001. pp 623-627.

\section{COMMUNICATIONS AND COMMENTS}

\section{Request for Existing Experimental Datasets on Color Differences}

Received 6 October 2006; accepted 13 October 2006

\begin{abstract}
The Technical Committee 1-55 of the International Commission on Illumination on "Uniform color space for industrial color difference evaluation" is requesting the submission of datasets for use in developing a new approximately uniform color space for industrial use. The data should be submitted to the TC Chair, Dr. Manuel Melgosa at the University of Granada. () 2007 Wiley Periodicals, Inc. Col Res Appl, 32, 159, 2007; Published online in Wiley InterScience (www.interscience.wiley.com). DOI $10.1002 / \mathrm{col} .20300$
\end{abstract}

Key words: color difference; CIE; CIEDE2000; uniform color space

The Technical Committee 1-55 of the International Commission on Illumination (CIE TC 1-55) on "Uniform color space for industrial color difference evaluation" is looking for existing experimental datasets on color differences complementing those employed during the development of the CIEDE2000 color-difference formula (Color Res Appl 2001;26:340-350). Reliable experimental datasets (that is, color pairs assessed by a considerable number of observers with nondefective color vision, under well controlled experimental conditions and using proper experimental methods) are requested. These datasets will be used to develop/test new color spaces with Euclidean color-difference formulas which may be useful for industrial applications. Not only surface specimens (object color), but also color pairs assessed using visual displays (e.g., CRT) can be considered. Experimental results obtained under illuminating/viewing conditions close to the "reference conditions" suggested for the CIEDE2000 color-difference formula (CIE Publication 142-2001) are particularly useful. Exact experimental conditions including the spectral power distribution of the viewing environment and the spectral reflectance factors or spectral radiance factors of the specimens are preferred. Researchers interested in having their experimental datasets considered by CIE TC 1-55 are kindly invited to contact the chairman of this TC. Please provide detailed information on the data: color coordinates and visual differences for color pairs (with their corresponding uncertainties or confidence limits, if possible), and a detailed description of the experimental conditions and method employed. Decisions as to the applicability of submitted data for the purposes of the work of the committee will be made by CIE TC 1-55.
Manuel Melgosa CIE TC 1-55 Chairman University of Granada Granada, Spain mmelgosa@ugr.es 